\title{
Review of Survey activities 2010
}

\section{Edited by}

Ole Bennike, Adam A. Garde and W. Stuart Watt 


\section{Geological Survey of Denmark and Greenland Bulletin 23}

\section{Keywords}

Geological Survey of Denmark and Greenland, survey organisations, current research, Denmark, Greenland.

\section{Cover photographs from left to right}

1. Small-scale miner with gold concentrate. Photograph: Peter W.U. Appel.

2. Work at the microscope. Photograph: Peter K. Warna-Moors.

3. Many Survey employees are engaged in laboratory work. Photograph: Peter K. Warna-Moors.

4. Development of geological models is becoming increasingly important. Photograph: Peter K. Warna-Moors.

\section{Frontispiece: facing page}

In 2010 the Survey carried out extensive mapping projects in the North Sea. The crane is carrying a tow-fish with (1) a side-scan sonar for mapping the seabed and (2) a chirp sonar for mapping the layers below the seabed. Photograph: Ole Bennike.

Chief editor of this series: Adam A. Garde

Editorial board of this series: John A. Korstgård, Department of Earth Sciences, University of Aarhus; Minik Rosing, Geological Museum,

University of Copenhagen; Finn Surlyk, Department of Geography and Geology, University of Copenhagen

Scientific editors: Ole Bennike, Adam A. Garde and W. Stuart Watt

Editorial secretaries: Jane Holst and Esben W. Glendal

Referees: (DK = Denmark etc.; numbers refer to first page of reviewed article): Anonymous (21, 37, 41, 53, 73), Niels Balling, DK (49); Jason Box, USA (73); Michele Crosetto, E (41); Gregers Dam, DK (61); David Lundbek Egholm, DK (69); Synnøve Elvevold, N (57); Ida Fabricius, DK (13); Rasmus Fensholt, DK (81); Tom Frisch, CND (69); Svend Funder, DK (29); Rikke Harlou, DK (57); Jens Havskov, N (49); Claus Heilmann-Clausen, DK (61); Rasmus Jakobsen, DK (45); John A. Korstgård, DK (53, 77); Gunnar Larsen, DK (45); Nicolaj Krog Larsen, S (33); Kaj Lax, S (77); Ole Bjørslev Nielsen, DK (17); Bent Odgaard, DK (29); Odleiv Olesen, N (81); Asger Ken Pedersen, DK (65); Gunver Krarup Pedersen, DK (17); Sandra Piazolo, S (65); Peter Sandersen, DK (25); Ulf Sivhed, S (9); Inga Sørensen, DK (21); Jette Sørensen, DK (25); Svend Stouge, DK (9); Szymon Uścinowicz, PL (37); Ole V. Vejbæk, DK (13); Jacob Clement Yde, N (33).

Illustrations: Stefan Sølberg, with contributions from Jette Halskov, Eva Melskens and Benny M. Schark

Layout and graphic production: Annabeth Andersen

Printers: Rosendahls · Schultz Grafisk A/S, Albertslund, Denmark

Manuscripts received: 21 December 2010 - 6 May 2011

Final versions approved: January-May 2011

Printed: 15 July 2011

ISSN 1603-9769 (Review of Survey activities)

ISSN 1604-8156 (Geological Survey of Denmark and Greenland Bulletin)

ISBN 978-87-7871-313-1

\section{Citation of the name of this series}

It is recommended that the name of this series is cited in full, viz. Geological Survey of Denmark and Greenland Bulletin. If abbreviation of this volume is necessary, the following form is suggested: Geol. Surv. Den. Green. Bull.23, 84 pp.

\section{Available from}

Geological Survey of Denmark and Greenland (GEUS)

Øster Voldgade 10, DK-1350 Copenhagen K, Denmark

Phone: +4538 142000, fax: +45381420 50, e-mail: geus@geus.dk

And at www.geus.dk/publications/bull

(c) De Nationale Geologiske Undersøgelser for Danmark og Grønland (GEUS), 2011

For the full text of the GEUS copyright clause, please refer to www.geus.dk/publications/bull 


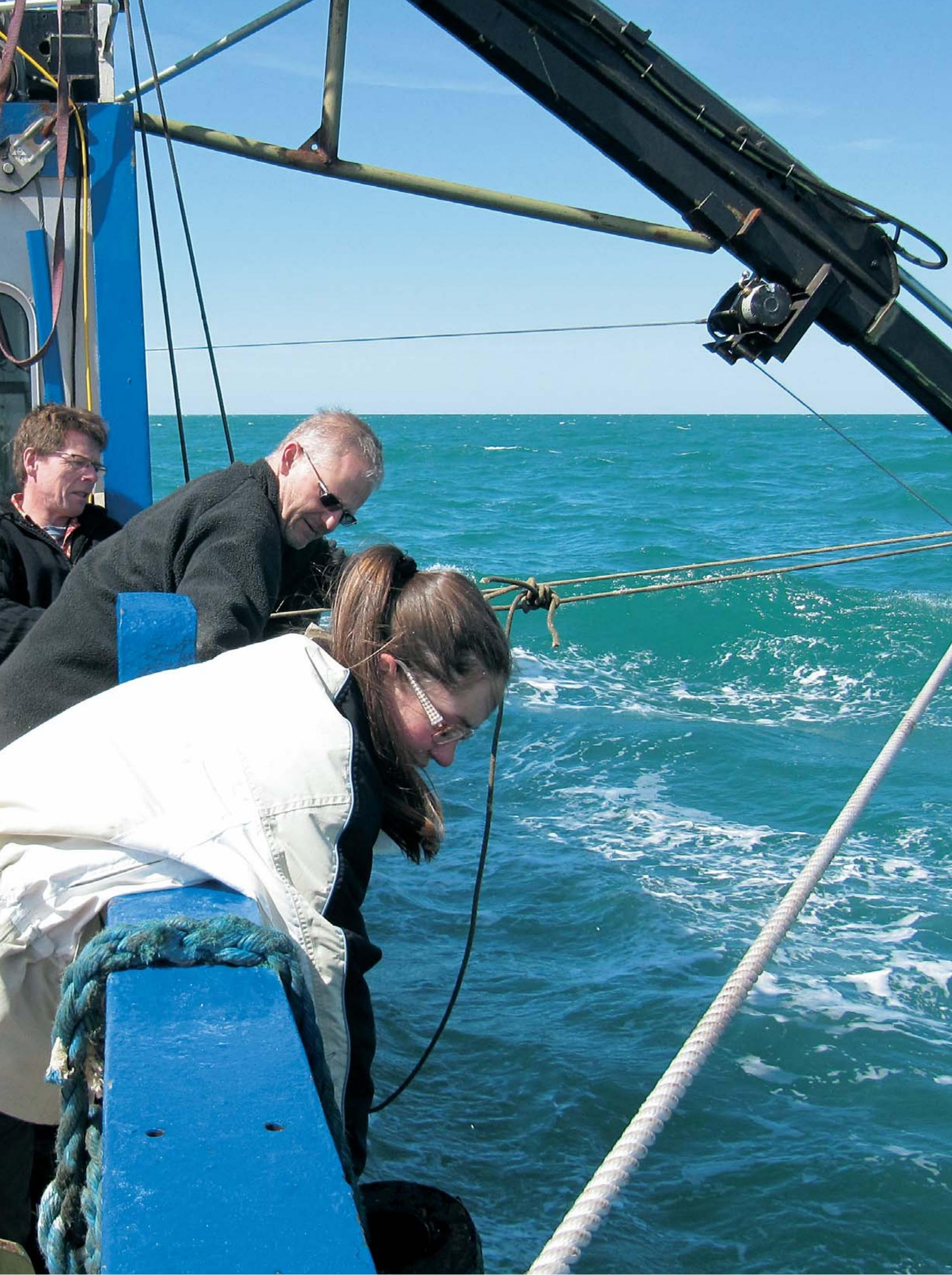




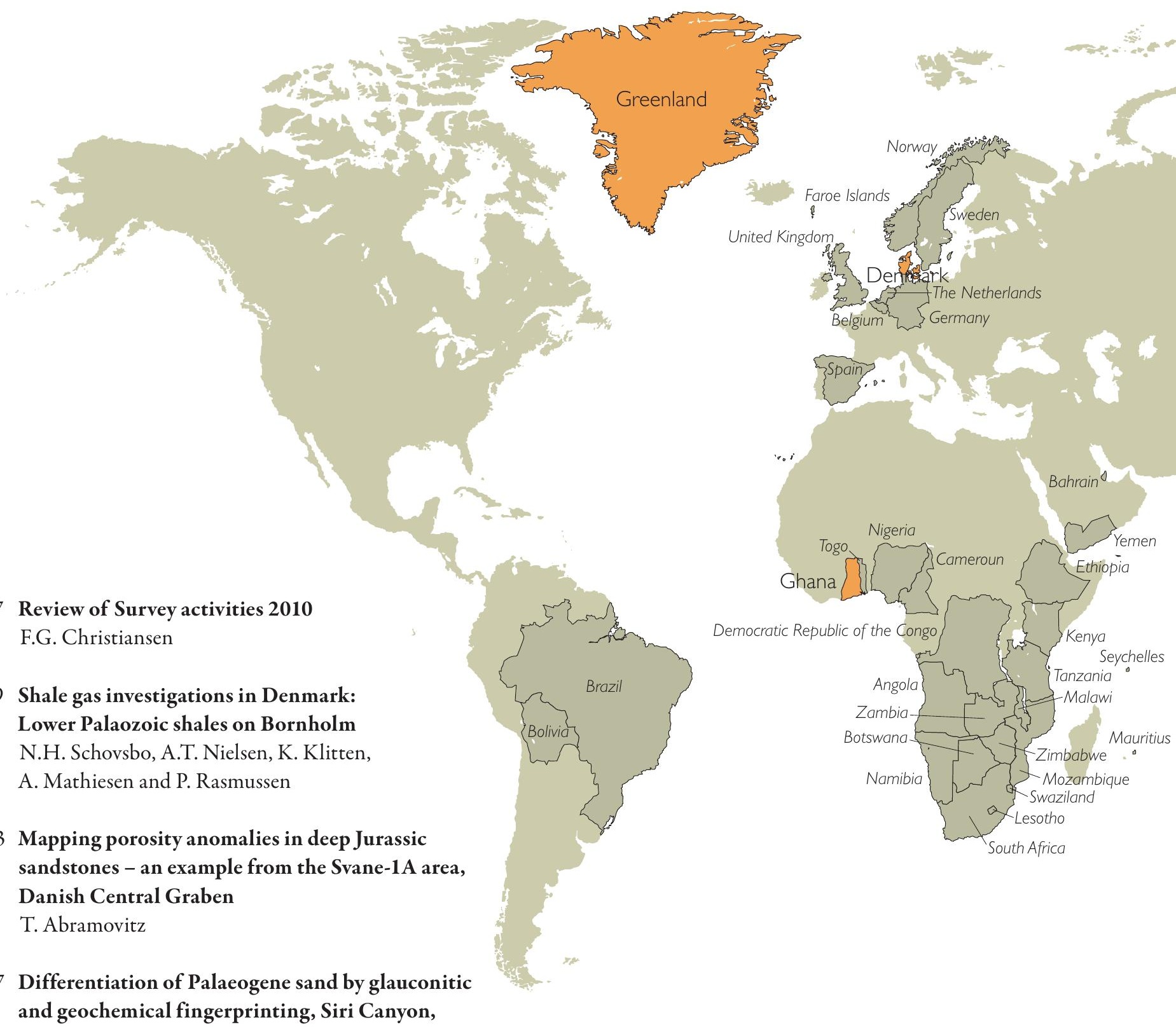

Danish North Sea

M. Olivarius, C. Knudsen and J.B. Svendsen

21 Geological characterisation of potential disposal areas for radioactive waste from Risø, Denmark P. Gravesen, M. Binderup, B. Nilsson and S.A.S. Pedersen

25 A digital, spatial, geological model of the Miocene in Jylland, Denmark

M. Kristensen, T. Vangkilde-Pedersen and E.S. Rasmussen

29 A new Middle Pleistocene interglacial sequence from Måløv, Sjælland, Denmark

O. Bennike, E. Lindgård, H.J. Granat, R.C. Preece and F. Viehberg

33 Mapping of raw materials and habitats in the Danish sector of the North Sea J.B. Jensen, S. Borre, J.O. Leth, Z. Al-Hamdani and L.G. Addington

37 Postglacial, relative shore-level changes in Lillebælt, Denmark

O. Bennike and J.B. Jensen

41 Detection of terrain changes in southern Denmark using persistent scatterer interferometry

S.A.S. Pedersen, G. Cooksley, M. Gaset and P.R. Jakobsen

45 Does road salt affect groundwater in Denmark? S.M. Kristiansen, F.D. Christensen and B. Hansen 



\title{
Review of Survey activities 2010
}

\author{
Flemming G. Christiansen
}

Deputy Director

2010 was a good and stable year for the Geological Survey of Denmark and Greenland (GEUS) with focus on research, often in international collaboration. Despite the continued effects of the international financial crisis, which has had serious implications for many of our national and international partners, GEUS has had a period with many new projects and successful completion of many projects. This is also reflected in the present eighth annual issue of Review of Survey activities which describes selected projects that GEUS and its partners carry out in Denmark, Greenland and internationally. Together with the previous seven published issues, it provides a good overview of the Survey's range of research and advisory activities. It contains a total of 19 four-page papers: 12 on Denmark, six on Greenland, and one project in Ghana.

Energy policy is again high on the political agenda in Denmark. The Government presented a new Energy 2050 Strategy with strong emphasis on the reduction of $\mathrm{CO}_{2}$ emission. The strategy depends on a stable supply of and income from oil and gas in the North Sea during a long transition period before most of Denmark's energy supply becomes $\mathrm{CO}_{2}$ neutral, competitive and stable. GEUS' research lies within a variety of different aspects of energy as well as of climate development, climate monitoring and adaptation to climate changes.

Three papers concentrate on various aspects of petroleum geology in Denmark. One of them provides an overview of a core-drilling project in Lower Palaeozoic shales on Bornholm as an unconventional shale gas resource analogue. Another paper describes mapping of very deep Jurassic targets in the Svane-1 area in the North Sea, and a third paper gives a geochemical fingerprinting of Palaeogene reservoir sands from the Siri Canyon in the North Sea and discusses the implications from being able to distinguish between in situ and mobilised sand.

GEUS works on many other aspects of the geology of Denmark, such as groundwater, climate and the environment including issues where geology is important to society.
Seven papers ranging from applied geology to more basic research are found in this volume. Decisions on disposal of Danish low- and intermediate-level radioactive waste have to be taken in the coming years, and a number of key geological parameters are used for the final selection of a permanent depository. The work has resulted in the selection of 22 areas, of which six are preferred.

The Miocene succession in Jylland contains several large groundwater bodies, and a 3D model is important for future planning; this is described in another paper. With a continued need for raw materials to large infrastructure projects, systematic mapping and understanding of available marine resources are important. The results from a project in the North Sea carried out for the Danish Nature Agency are presented in one paper. Two papers describe basic research on a new Pleistocene interglacial sequence from Sjælland and on postglacial relative shore-level changes in Lillebælt. Another paper presents results of the detection of terrain changes using satellite data with south-western Jylland as a case. One paper discusses how sensitive the groundwater quality in Denmark is to the use of road salt in winter. The Danish contribution to the Nuclear-Test-Ban Treaty is also described, demonstrating how useful the data from the monitoring systems are for understanding earthquakes.

In 2010, there was a high level of field activities in Greenland. In addition to major projects in southern West Greenland, South-East Greenland and North-East Greenland there were many smaller activities in other areas. The work in southern West Greenland continued, and results are described in a paper on the Tartoq Group, a possible very old slab of oceanic crust. Field work and shallow core drilling in North-East Greenland continued in 2010. In this issue results on previously almost unknown Palaeogene sand are presented, including new critical information on age and depositional environment. Structural data from the Sødalen area in southern East Greenland are presented in a paper that concentrates on unravelling the strike-slip tectonics in Palaeogene time. One paper adds additional evidence from magnetic data contra- 
dicting the existence of a major structural feature (the Wegener Fault) in the Kennedy Channel between North Greenland and Ellesmere Island in Canada.

Studies of the ice sheet and glaciers in Greenland have attracted international interest over many years due to the possible implications of a rising sea level. GEUS is involved in many glaciological and meteorological projects and monitoring programmes. One paper gives a presentation on the large-scale Programme for Monitoring of the Greenland Ice Sheet (PROMICE) with description of the weather station network and preliminary temperature data.

Easy access to comprehensive and updated information and data is a very important part of the work GEUS carries out in Denmark and Greenland. This is the topic of two papers, one on free, online Danish geological data where the Jupiter database currently includes information from more than 260000 shallow wells. The other paper gives a description of DODEX (Geoscience Documents and Data for Exploration in Greenland), which is an interactive web application, which gives the public and mining companies easy access to all non-confidential reports relevant to mineral exploration.

Internationally GEUS works in many different countries with many project types. The last paper in this issue is about work in Ghana where GEUS has been active for many years with capacity building and geological and geophysical projects. The paper gives an overview of quality control of airborne geophysical data. 